\title{
The 50 Most Cited Papers in Craniofacial Anomalies and Craniofacial Surgery
}

\author{
Nicola A Mahon ${ }^{1}$, Cormac W Joyce ${ }^{1}$, Sangeetha Thomas ${ }^{2}$, Elizabeth Concannon ${ }^{1}$, Dylan Murray ${ }^{3}$ \\ ${ }^{1}$ Department of Plastic and Reconstructive Surgery, University Hospital Galway, Galway, Ireland; ${ }^{2}$ Department of Oral and Maxillofacial \\ Surgery, Peterborough Hospital, Cambridge, UK; ${ }^{3}$ Department of Plastic, Reconstructive and Craniofacial Surgery, Temple Street Children's \\ Hospital, Dublin, Ireland
}

Background Citation analysis is a recognized scientometric method of classifying cited articles according to the frequency of which they have been referenced. The total number of citations an article receives is considered to reflect it's significance among it's peers.

Methods Until now, a bibliometric analysis has never been performed in the specialty of craniofacial anomalies and craniofacial surgery. This citation analysis generates an extensive list of the 50 most influential papers in this developing field. Journals specializing in craniofacial surgery, maxillofacial surgery, plastic surgery, neurosurgery, genetics and pediatrics were searched to demonstrate which articles have cultivated the specialty within the past 55 years.

Results The results show an intriguing compilation of papers which outline the fundamental knowledge of craniofacial anomalies and the developments of surgical techniques to manage these patients.

Conclusions This citation analysis provides a summation of the current most popular trends in craniofacial literature. These esteemed papers aid to direct our decision making today within this specialty.

Keywords: Bibliometrics / Analysis / Craniofacial abnormality / Anomalies
Correspondence: Nicola A Mahon Department of Plastic and

Reconstructive Surgery, University Hospital Galway, Newcastle Road,

Galway, Ireland

Tel: +353-876695584

Fax: +353-1-6268362

E-mail: nicolamahon@rcsi.ie

\section{INTRODUCTION}

Craniofacial anomalies represent a diverse group of congenital disorders. They occur due to the abnormal development of the bones and associated soft tissues of the skull and face. Craniofacial syndromes can be divided into those affected by the premature fusion of the cranial sutures (craniosynostosis) and those affected by clefts [1].

Craniosynostosis occurs in 1 in 2,000 of the population. Syndromic craniosynostoses, such as Crouzon and Apert syndromes occur in 1 in 10,000 and 1 in 150,000 live births respectively [2]. Commonly seen craniofacial conditions in children include su- ture synostosis, Apert, Crouzon, Saethre-Chotzen, Pfeiffer, midfacial clefts, microsomias, and cephalic abnormalities. These developmental disorders have far reaching consequences on the airway, appearance, cerebral development, hearing, sight, dentition, speech and psychological well-being of these patients. Surgical management comprises of distraction techniques, orthognathic procedures and tumor resections. Owing to the wide array of surgeries within this field, multidisciplinary input becomes a requisite [3].

Over the years, newly recognized associated craniofacial syndromes and advances in surgical procedures have been documented in the literature by different specialties. Due to the di- 
versity of specialties involved in this area, it is extremely difficult to be aware of the most influential papers. The citation frequency of a published paper determines its influence within it's specific field. A citation is a numerical abbreviation embedded within the text of an article, which refers to and acknowledges another author's work. Citation analysis is a recognized bibliometric method whereby papers are ranked according to the number of times they have been referenced. Hence, citation analysis is an established method to determine the degree of influence of a paper within a specialist field. The purpose of a citation is also to ascertain the impact of an important piece of work contributed by a specific author. The impact factor (IF) of a scientific journal is a measure of the number of citations it's published articles have received [4]. It is a calculation based on the number of citations a journal has obtained in the current year to items published over the previous two years, divided by the substantive articles published over the previous two years $[5,6]$. The higher the IF of a journal, the more prestigious it becomes within the scientific community which it serves [7]. As a result, the IF of the publishing journal is also enhanced when a key paper is within its bibliography. Although the validity of this method is disputable in defining a journal's worth, many scientific journals still aim to improve their IF, recognizing this as a fundamental marker of journal quality $[8,9]$. Several articles on citation classics have been published in various specialities including anaesthetics, general surgery, otolaryngology, plastic surgery, radiology and orthopaedics [10-15]. However, there has never been a bibliometric analysis of the most cited papers in the field of craniofacial anomalies and surgery. In this study, we have performed a citation analysis to evaluate the 50 most influential papers in craniofacial anomalies and surgery over the past 55 years.

\section{METHODS}

The database of the Science Citation Index (SCI) of the Institute for Scientific Information (ISI) was utilized in order to identify the most cited papers in craniofacial anomalies and surgery [16]. This is an online index of citations, available through the Web of Science database, which is part of the Web of Knowledge collection of databases. In our search performed between March and April 2015, 64 international scientific journals were included (Table 1). The included journals consisted of craniofacial, plastics, maxillofacial, genetics and paediatric journals with high IF. Only 18 of these 64 journals contributed to the top fifty most cited articles. Papers that dealt exclusively with cleft lip and palate were excluded from the search as citation analysis on this subject has been published before [17].

The database was searched using filter terms of 'craniofacial
Table 1. The journals and the number of papers each journal contributed to the top 50 papers

\begin{tabular}{|c|c|}
\hline Journal name & Number \\
\hline Nature Genetics & 13 \\
\hline Plastic and Reconstructive Surgery & 8 \\
\hline American Journal of Medical Genetics & 5 \\
\hline Americal Journal of Human Genetics & 5 \\
\hline Journal of Oral and Maxillofacial Surgery & 4 \\
\hline Journal of Medical Genetics & 2 \\
\hline Journal of Neurosurgery & 2 \\
\hline Journal of Cranio-Maxillofacial Surgery & 1 \\
\hline Cleft Palate Craniofacial Journal & 1 \\
\hline Paediatrics & 1 \\
\hline Neurosurgery & 1 \\
\hline Annals of Plastic Surgery & 1 \\
\hline Trends in Genetics & 1 \\
\hline Annals of Human Genetics & 1 \\
\hline Nature reviews Genetics & 1 \\
\hline Human Molecular Genetics & 1 \\
\hline Journal of Craniofacial Genetics and Developmental Biology & 1 \\
\hline Journal of Craniofacial Surgery & 1 \\
\hline \multicolumn{2}{|c|}{$\begin{array}{l}\text { Other journals included in our search but which did not achieve top } 50 \text { status: } \\
\text { Clinics in Plastic Surgery, J Plast Reconstr Aesthet Surg, Archives of Plastic Sur- } \\
\text { gery, Scandinavian Journal of plastic, reconstructive and hand surgery, European } \\
\text { Journal of Plastic Surgery, Facial Plastic Surgery, Aesthetic Plastic Surgery, Archi- } \\
\text { ves of Facial Plastic Surgery, Orthodontics Craniofacial Research, British Journal } \\
\text { Of Maxillo-facial Surgery, International Journal of Maxillio-facial Surgery, Journal } \\
\text { of Maxillofacial Surgery, Journal of Paediatrics and Child Health, Paediatrics Child } \\
\text { Health, Clinical Pediatrics, European Journal of Pediatrics, Indian Pediatrics, Indian } \\
\text { Journal of Pediatrics, Journal of Pediatrics, Pediatrics International, Rivista Italiana } \\
\text { Di Pediatria Italian, Turkish Journal of Pediatrics, Animal Genetics, Behavior Ge- } \\
\text { netics, BMC Genetics, BMC Medical Genetics, Canadian Journals of Genetics } \\
\text { and Cytology, Cancer Genetics and Cytogenetics, Clinical Genetics, Current Ge- } \\
\text { netics, Cytogenetics and Cell Genetics, European Journal of Human Genetics, } \\
\text { European Journal of Medical Genetics, Genetics, Genetics and Molecular Re- } \\
\text { search, Genetics in Medicine, Human Genetics, Japanese Journal of Genetics, } \\
\text { Japanese Journal Of Human Genetics, Journal of Medical Genetics, Korean Journal } \\
\text { of Genetics, Molecular General Genetics, Molecular Genetics and Metabolism, } \\
\text { PLOS Genetics, Russian Journal of Genetics, Theoretical and Applied Genetics } \\
\text { and Trends in Genetics. }\end{array}$} \\
\hline
\end{tabular}

anomalies,' 'cranial synostosis,' 'Apert's syndrome', 'Crouzon's syndrome, 'Pierre Robin Sequence, 'Treacher Collins', 'Nager syndrome, 'Pfeiffer syndrome, 'Goldenhar,' 'microsomia, 'facial clefts, 'plagiocephaly', trigonocephaly,' 'brachycephaly', 'scaphocephaly', 'distraction osteogenesis', 'maxillary/mandibular advancement', 'monobloc', 'orthognathic', 'cranial vault', 'skull base surgery', 'Lefort 1', 'tumors' and 'trauma'. Once the fifty most cited papers were identified, a further analysis of each paper using criteria described by Paladugu et al. [11] was performed. This involved evaluating each individual paper to reveal it's subject matter, authorship, article type, institution and year of publication.

\section{RESULTS}

Table 2 represents the fifty most cited papers in craniofacial ano- 
Table 2. The 50 most cited papers in Craniofacial Anomalies and Craniofacial Surgery

\begin{tabular}{|c|c|c|c|}
\hline Rank & Paper & First author & $\begin{array}{l}\text { No of } \\
\text { citations }\end{array}$ \\
\hline 1 & McCarthy JG, Schreiber J, Karp N, et al. Lengthening the human mandible by gradual distraction. Plast Reconstr Surg 1992;89:1-8. & McCarthy JG & 1,047 \\
\hline 2 & $\begin{array}{l}\text { Ryan AK, Goodship JA, Wilson DI, et al. Spectrum of clinical features associated with interstitial chromosome } 22 \text { q11 deletions: a } \\
\text { European collaborative study. J Med Genet 1997;34:798-804. }\end{array}$ & Ryan AK & 612 \\
\hline 3 & $\begin{array}{l}\text { Satokata I, Maas R. MSX1 deficient mice exhibit cleft-palate and abnormalities of craniofacial and tooth development. Nat Genet } \\
\text { 1994;6:348-56. }\end{array}$ & Satokata I & 810 \\
\hline 4 & $\begin{array}{l}\text { Loeys BL, Chen JJ, Neptune ER, et al. A syndrome of altered cardiovascular, craniofacial, neurocognitive and skeletal development } \\
\text { caused by mutations in TGFBR1 or TGFBR2. Nat Genet 2005;37:275-81. }\end{array}$ & Loeys BL & 591 \\
\hline 5 & Jerome LA, Papaioannou VE. DiGeorge syndrome phenotype in mice mutant for the T-box gene, Tbx1. Nat Genet 2001;27:286-91. & Jerome LA & 503 \\
\hline 6 & $\begin{array}{l}\text { Wilkie AOM, Slaney SF, Oldridge M, et al. Apert syndrome results from localized mutations of FGFR2 and is allelic with Crouzon } \\
\text { syndrome. Nat Genet 1995;9:165-72. }\end{array}$ & Wilkie AOM & 546 \\
\hline 7 & $\begin{array}{l}\text { Reardon W, Winter RM, Rutland P, et al. Mutations in the fibroblast growth-factor receptor-2 gene cause Crouzon-syndrome. Nat Genet } \\
\text { 1994;8:98-103. }\end{array}$ & Reardon W & 472 \\
\hline 8 & $\begin{array}{l}\text { Muenke M, Schell U, Hehr A, et al. A common mutation in the fibroblast growth-factor receptor-1 gene in Pfeiffer syndrome. Nat Genet } \\
\text { 1994:8:269-74. }\end{array}$ & Muenke M & 431 \\
\hline 9 & $\begin{array}{l}\text { Zins JE, Whitaker LA. Membranous versus endochondral bone - implications for craniofacial reconstruction. Plast Reconstr Surg } \\
\text { 1983;72:778-84. }\end{array}$ & Zins JE & 421 \\
\hline 10 & $\begin{array}{l}\text { El Ghouzzi V, LeMerrer M, PerrinSchmitt F, et al. Mutations of the TWIST gene in the Saethre-Chotzen syndrome. Nat Genet } \\
\text { 1997;15:42-6. }\end{array}$ & El Ghouzzi V & 371 \\
\hline 11 & $\begin{array}{l}\text { Howard TD, Paznekas WA, Green ED, et al. Mutations in TWIST, a basic helix-loop-helix transcription factor, in Saethre-Chotzen } \\
\text { syndrome. Nat Genet 1997;15:36-41. }\end{array}$ & Howard TD & 360 \\
\hline 12 & Wilson DI, Burn J, Scambler P, et al. DiGeorge-Syndrome - Part of CATCH-22. J Med Genet 1993;30:852-856. & Wilson DI & 355 \\
\hline 13 & $\begin{array}{l}\text { Jabs EW, Li X, Scott AF, et al. Jackson-Weiss-Syndrome and Crouzon-Syndrome are allelic with mutations in fibroblast growth-factor } \\
\text { Receptor-2. Nat Genet 1994;8:275-9. }\end{array}$ & Jabs EW & 347 \\
\hline 14 & $\begin{array}{l}\text { Chin M, Toth BA. Distraction osteogenesis in maxillofacial surgery using internal devices: Review of five cases. J Oral and Maxillofac } \\
\text { Surg 1996;54:45-53. }\end{array}$ & Chin M & 345 \\
\hline 15 & $\begin{array}{l}\text { Rutland P, Pulleyn LI, Reardon W, et al. Identical mutations in the fgfr2 gene cause both Pfeiffer and Crouzon syndrome phenotypes. } \\
\text { Nat Genet 1995;9:173-6. }\end{array}$ & Rutland P & 327 \\
\hline 16 & $\begin{array}{l}\text { Tessier P. Definitive plastic surgical treatment of severe facial deformities of Craniofacial dysostosis - Crouzons and Aperts diseases. } \\
\text { Plast Reconstr Surg 1971;48:419-42. }\end{array}$ & Tessier P & 313 \\
\hline 17 & Goldberg R, Motzkin B, Marion R, et al. Velo-cardio-facial syndrome: a review of 120 patients. Am J Med Genet 1993;45:313-9. & Goldberg R & 311 \\
\hline 18 & Wilkie AOM. Craniosynostosis: Genes and Mechanisms. Hum Mol Genet 1997;6:1647-56. & Wilkie AOM & 302 \\
\hline 19 & Shillito J, Matson DD. Craniosynostosis: a review of 519 surgical patients. Pediatrics 1968;41:829-53. & Shillito J & 302 \\
\hline 20 & $\begin{array}{l}\text { Driscoll DA, Spinner NB, Budarf ML, et al. Deletions and microdeletions of 22Q11.2 in velo-cardio-facial syndrome. Am J Med Genet } \\
\text { 1992;44:261-8. }\end{array}$ & Driscoll DA & 296 \\
\hline 21 & $\begin{array}{l}\text { Novelli G, Muchir A, Sangiuolo F, et al. Mandibuloacral dysplasia is caused by a mutation in LMNA-encoding lamin A/C. Am J Hum } \\
\text { Genet 2002;71:426-31. }\end{array}$ & Novelli G & 283 \\
\hline 22 & $\begin{array}{l}\text { Shprintzen RJ, Goldberg R, Goldingkushner KJ, et al. Late-onset psychosis in the velo-cardio-facial syndrome. Am J Med Genet } \\
\text { 1992;42:141-2. }\end{array}$ & Shprintzen RJ & 280 \\
\hline 23 & $\begin{array}{l}\text { Polley JW, Figueroa AA. Management of severe maxillary deficiency in childhood and adolescence through distraction osteogenesis } \\
\text { with an external, adjustable, rigid distraction device. J Craniofac Surg 1997:8:181-5. }\end{array}$ & Polley JW & 253 \\
\hline 24 & $\begin{array}{l}\text { Buser D, Dula K, Hirt HP, et al. Lateral ridge augmentation using autografts and barrier membranes: a clinical study with } 40 \text { partially } \\
\text { edentulous patients. J Oral and Maxillofac Surg 1996;54:420-32. }\end{array}$ & Buser D & 231 \\
\hline 25 & $\begin{array}{l}\text { Muenke M, Gripp KW, McDonald-McGinn DM, et al. A unique point mutation in the fibroblast growth factor receptor } 3 \text { gene (FGFR3) } \\
\text { defines a new craniosynostosis syndrome. Am J Hum Genet 1997;60:555-64. }\end{array}$ & Muenke M & 231 \\
\hline 26 & $\begin{array}{l}\text { Gay E, Sekhar LN, Rubinstein E, et al. Chordomas and chondrosarcomas of the cranial base - results and follow-up of } 60 \text { patients. } \\
\text { Neurosurgery 1995;36:887-96. }\end{array}$ & Gay $E$ & 226 \\
\hline 27 & Cohen MM. Sutural biology and the correlates of craniosynostosis. Am J Med Genet 1993;47:581-616. & Cohen MM & 225 \\
\hline 28 & $\begin{array}{l}\text { Carlson C, Sirotkin H, Pandita R, et al. Molecular definition of 22q11 deletions in } 151 \text { velo-cardio-facial syndrome patients. Am J Hum } \\
\text { Genet 1997;61:620-9. }\end{array}$ & Carlson C & 221 \\
\hline 29 & $\begin{array}{l}\text { Bellus GA, Gaudenz K, Zackai EH, et al. Identical mutations in three different fibroblast growth factor receptor genes in autosomal } \\
\text { dominant craniosynostosis syndromes. Nat Genet 1996;14:174-6. }\end{array}$ & Bellus GA & 217 \\
\hline 30 & Karp NS, Thorne CH, McCarthy JG, et al. Bone lengthening in the craniofacial skeleton. Ann Plast Surg 1990;24:231-7. & Karp NS & 216 \\
\hline 31 & $\begin{array}{l}\text { Kent JN, Block MS. Simultaneous maxillary sinus floor bone-grafting and placement of hydroxylapatite-coated implant. J Oral and } \\
\text { Maxillofac Surg 1989;47:238-42. }\end{array}$ & Kent JN & 213 \\
\hline 32 & $\begin{array}{l}\text { Blank CE. Apert's syndrome (a type of acrocephalosyndactyly)-observations on a British series of thirty-nine cases. Ann Hum Genet } \\
\text { 1960;24:151-64. }\end{array}$ & Blank CE & 211 \\
\hline 33 & $\begin{array}{l}\text { Lachman HM, Morrow B, Shprintzen R, et al. Association of codon 108/158 catechol-0-methyltransferase gene polymorphism with the } \\
\text { psychiatric manifestations of velo-cardio-facial syndrome. Am J Med Genet 1996;67:468-72. }\end{array}$ & Lachman HM & 211 \\
\hline
\end{tabular}




\begin{tabular}{|c|c|c|c|}
\hline Rank & Paper & First author & $\begin{array}{l}\text { No of } \\
\text { citations }\end{array}$ \\
\hline 34 & $\begin{array}{l}\text { Greenberg F, Guzzetta V, Montes de Oca-Luna R, et al. Molecular analysis of the Smith-Magenis syndrome: a possible contiguous-gene } \\
\text { syndrome associated with 17p11.2. Am J Hum Genet 1991;49:1207-18. }\end{array}$ & Greenberg F & 204 \\
\hline 35 & Wilkie AO, Morriss-Kay GM. Genetics of craniofacial development and malformation. Nat Rev Genet 2001;2:458-68. & Wilkie AOM & 198 \\
\hline 36 & $\begin{array}{l}\text { Mulliken JB, Glowacki J. Induced osteogenesis for repair and construction in the craniofacial region. Plast Reconstr Surg 1980;65:553- } \\
\text { 9. }\end{array}$ & Mulliken JB & 192 \\
\hline 37 & $\begin{array}{l}\text { Goldingkushner KJ, Weller G, Shprintzen RJ. Velo-cardio-facial syndrome: language and psychological profiles. J Craniofac Genet Dev } \\
\text { Biol 1985;5:259-66. }\end{array}$ & $\begin{array}{l}\text { Goldingkushner } \\
\text { KJ }\end{array}$ & 192 \\
\hline 38 & $\begin{array}{l}\text { Sekhar LN, Nanda A, Sen CN, et al. The extended frontal approach to tumors of the anterior, middle, and posterior skull base. J } \\
\text { Neurosurg 1992;76:198-206. }\end{array}$ & Sekhar LN & 192 \\
\hline 39 & $\begin{array}{l}\text { Moy PK, Lundgren S, Holmes RE. Maxillary sinus augmentation: histomorphometric analysis of graft materials formaxillary sinus floor } \\
\text { augmentation. J Oral and Maxillofac Surg 1993;51:857-62. }\end{array}$ & Moy PK & 192 \\
\hline 40 & $\begin{array}{l}\text { Robertson SP, Twigg SR, Sutherland-Smith AJ, et al. Localized mutations in the gene encoding the cytoskeletal protein filamin A cause } \\
\text { diverse malformations in humans. Nat Genet 2003;33:487-91. }\end{array}$ & Robertson SP & 189 \\
\hline 41 & Krumlauf R. Hox genes and pattern-formation in the branchial region of the vertebrate head. Trends Genet 1993;9:106-12. & Krumlauf $\mathrm{R}$ & 188 \\
\hline 42 & $\begin{array}{l}\text { Morrow B, Goldberg R, Carlson C, et al. Molecular definition of the 22q11 deletions in velo-cardio-facial syndrome. Am J Hum Genet } \\
\text { 1995;56:1391-403. }\end{array}$ & Morrow B & 183 \\
\hline 43 & $\begin{array}{l}\text { Berenguer B, Burrows PE, Zurakowski D, et al. Sclerotherapy of craniofacial venous malformations: Complications and results. Plast } \\
\text { Reconstr Surg 1999;104:1-11. }\end{array}$ & Berenguer B & 182 \\
\hline 44 & $\begin{array}{l}\text { Gassner R, Tuli T, Hachl 0, et al. Cranio-maxillofacial trauma: a } 10 \text { year review of } 9543 \text { cases with } 21067 \text { injuries. J Craniomaxillofac } \\
\text { Surg 2003;31:51-61. }\end{array}$ & Gassner R & 179 \\
\hline 45 & Anderson FM, Geiger L. Craniosynostosis: a survey of 204 cases. J Neurosurg 1965;22:229-40. & Anderson FM & 177 \\
\hline 46 & $\begin{array}{l}\text { Whitaker LA, Munro IR, Salyer KE, et al. Combined report of problems and complications in } 793 \text { craniofacial operations. Plast Reconstr } \\
\text { Surg 1979;64:198-203. }\end{array}$ & Whitaker LA & 174 \\
\hline 47 & $\begin{array}{l}\text { Whitaker LA, Bartlett SP, Schut L, et al. Craniosynostosis: an analysis of the timing, treatment, and complications in } 164 \text { consecutive } \\
\text { patients. Plast Reconstr Surg 1987;80:195-206. }\end{array}$ & Whitaker LA & 173 \\
\hline 48 & $\begin{array}{l}\text { Waitzman AA, Posnick JC, Armstrong DC, et al. Craniofacial skeletal measurements based on computed tomography: Part II. Normal } \\
\text { values and growth trends. Cleft Palate Craniofac J 1992;29:118-28. }\end{array}$ & Waitzman AA & 170 \\
\hline 49 & $\begin{array}{l}\text { Wilkie AO, Tang Z, Elanko N, et al. Functional haploinsufficiency of the human homeobox gene MSX2 causes defects in skull } \\
\text { ossification. Nat Genet 2000;24:387-90. }\end{array}$ & Wilkie AOM & 170 \\
\hline 50 & $\begin{array}{l}\text { Tessier P. Relationship of Craniostenoses to craniofacial dysostoses, and to faciostenoses - study with therapeutic implications. Plast } \\
\text { Reconstr Surg 1971;48:224-37. }\end{array}$ & Tessier P & 169 \\
\hline
\end{tabular}

malies and craniofacial surgery, in descending rank order of citations received. The total number of citations per articles ranged from 1,047 to 169 (Table 2). The most influential paper was cited 1,047 times and was published by McCarthy et al. in 1992 . This seminal article described a novel technique to lengthen the mandible by gradual distraction. Four patients were recruited and the concept was that this technique would provide early reconstruction of craniofacial defects without the need for bone grafts, blood transfusion or intermaxillary fixation (Table 2). The second most frequently cited paper by Ryan et al consisted of a European collaborative study determining the features of 22 q11 deletions. This was a large multicenter trial consisting of $11 \mathrm{UK}$ institutes and 12 institutes from seven other European countries. Data was obtained regarding 558 patients with DiGeorge syndrome to elucidate a spectrum of clinical features to aid in its recognition (Table 2). The next most cited papers deal with the recognition of mutations in Msxl (MSH homeobox 1), TBX (T-box), FGFs (Fibroblast Growth Factor) receptor and TWIST genes in the genesis of Apert, Crouzon, Pfeiffer and Saethre- Chotzen syndromes. The 9 th most cited paper was published by Zins et al in 1983 and it compared the use of membranous versus endochondrial bone in craniofacial reconstruction. It is not until the 14th position that the next surgical paper is ranked in the top 50 list. It was published by Chin et al. in 1996. The subject matter again comprised of distraction osteogenesis and advocated its use to eliminate scarring, improve patient compliance and improve stability when compared to the biphasic systems that were in use at that time.

Nature Genetics published thirteen of the most cited papers, establishing it as the journal with the highest number of papers in the top 50 list (Table 2). The surgical journals Plastic and Reconstructive Surgery and the Journal of Oral and Maxillofacial Surgery, ranked highest for surgical journals having published 8 and 4 papers respectively in the top 50 most cited list. The 1990's contributed the majority of papers having published 32 articles, the remainder were derived mostly from the 2000's (Table 3). Seven countries contributed to the top 50 papers. Most articles originated from the USA which were responsible for publishing 32 papers in the top 50 (Table 4). English- speaking countries produced 44 of the top 50 papers (United States, United King- 
dom, Canada), whilst the remaining 6 articles originated from countries where English is not the first language (France, Switzerland, Austria, and Italy).

The Institute of Molecular Medicine in the John Radcliffe Hospital in Oxford United Kingdom contributed most of the papers to the top 50 list (Table 5). The subject matter focused mainly on genetics (20 papers), surgical management with distraction or bone grafts (14 papers) features of specific syndromes ( $7 \mathrm{pa}-$ pers) and craniosynostosis (4 papers). Facial growth patterns, psychology, vascular malformations and trauma were featured to a lesser extent, accounting for the remaining 5 papers in the top 50 papers. The author Shprintzen from the department of plastic surgery in the Montefiore Medical Centre in New York was the most prolific author having been involved in 7 papers in the top 50 most cited list. AOM Wilkie from the John Radcliffe Hospital in Oxford achieved the most first author publications

\section{Table 3 . The decades which generated the top 50 papers}

\begin{tabular}{|lc|}
\hline Decade & No. of papers \\
\hline 1960 's & 3 \\
1970 's & 3 \\
1980 's & 5 \\
1990 's & 32 \\
2000 's & 7 \\
\hline
\end{tabular}

Table 4. The countries of origin of the top $\mathbf{5 0}$ papers in Craniofacial Anomalies and Surgery

\begin{tabular}{|lc|}
\hline Nation & No. of papers \\
\hline USA & 32 \\
UK & 11 \\
France & 3 \\
Canada & 1 \\
Italy & 1 \\
Austria & 1 \\
Switzerland & 1 \\
\hline
\end{tabular}

in this list (Table 6).

\section{DISCUSSION}

The comprehensive management of craniofacial anomalies and the expansion of craniofacial surgery has evolved over the past 55 years. Historically patients were denied treatment due to the

Table 6. The authors who contributed more than one article to the top 50 papers

\begin{tabular}{|lcc|}
\hline Author & $\begin{array}{c}\text { No. of } \\
\text { papers }\end{array}$ & \multicolumn{1}{c|}{ Position on authors list } \\
\hline Shprintzen RJ & 7 & 1st, 3rd (twice i.e.,. last), 5th, 7th, 10th, and \\
& \multicolumn{1}{c|}{ 12th author } \\
Wilkie AOM & 6 & 1st (4 times), 25th, and last author \\
Goldberg R & 6 & 1st, 2rd (twice), 4th, 6th, and 7th author \\
Whitaker LA & 5 & 1st (twice), 2nd, and 5th author (twice i.e., last) \\
Malcolm S & 4 & 6th, 7th (last), and 10th author \\
Scambler P & 4 & 3rd, 4th, 9th, 11th, and 25th author \\
Rutland P & 4 & 1st, 3rd, 8th, and 10th author \\
Winter RM & 3 & 2nd, 8th, and 22nd author \\
Reardon W & 3 & 1st, 3rd and 9th author \\
Muenke M & 3 & 1st (twice), and 7th (last) author \\
Thorne CH & 2 & 2nd and 4th author \\
Wilson DI & 2 & 1st and 3rd author \\
Slaney SF & 2 & 2nd and 10th author \\
Oldridge M & 2 & 3rd and 9th author \\
Karp N & 2 & 1st and 3rd author \\
Tessier P & 2 & 1st author (twice) \\
Jackson CE & 2 & 4th and 9th author \\
Jabs EW & 2 & 1st and 10th (last) author \\
Marion R & 2 & 3rd and 4th (last) author \\
Twigg SR & 2 & 2nd and 5th author \\
McCarthy J & 2 & 1st and 3rd author \\
Robin N & 2 & 4th and 8th author \\
Carlson C & 2 & 1st and 3rd author \\
Morrow BE & 2 & 2nd and 14th (last) author \\
Mulliken JB & 3 & 1st, 4th, and 12th author \\
Pulleyn LJ & 2 & 2nd and 4th author \\
Jones BM & 2 & 5th and 6th author \\
Sekhar LN & 2 & 1st and 2nd author \\
\hline & & \\
& &
\end{tabular}

Table 5. The institutions which contributed greater than one paper to the top $\mathbf{5 0}$ most cited papers in Craniofacial Anomalies \& Craniofacial Surgery

\section{Institution}

Institute of Molecular MedicineJohn Radcliffe Hospital, Headington, Oxford, UK

Dept of Paeds/Genetics, John Hopkins medical school, Baltimore, USA

Dept of Plastics/Craniofacial disorders, Montefiore Medical Centre, Bronx, New York, USA

Childrens Hospital of Philadelphia, USA

Division of Plastic Surgery/Paeds, Obstetrics, University of Pennsylvania school of Medicine, Philadelphia, USA

Dept of Molecular Genetics, Albert Einstein College of Medicine, Bronx, NY, USA

Childrens Hospital, Harvard Medical School, Massachusetts, USA

Mothercare unit of clinical development and fetal Medicine, Institute of Child Health, London, UK

Dept of Neurosurgery, University of Pittsburg, USA
No. of papers

\begin{tabular}{l|}
5 \\
3 \\
3 \\
3 \\
3 \\
3 \\
3 \\
2 \\
2
\end{tabular}


high morbidity and mortality of surgical intervention [2]. Now, with the introduction of the multidisciplinary team approach to treatment, the care of these patients has been transformed [3]. Most of our improved knowledge and surgical skills are as a direct result of advances in scientific research in this field. Considering the multiple specialties involved in the care of these patients, it is quite challenging to be conversant with current developments within each field.

The aim of this study was to identify the 50 most cited papers published in the area of craniofacial anomalies and craniofacial surgery. The results of this research elucidate how developments in this specialty have evolved over time. It becomes apparent which authors have made outstanding contributions in this area and led the way in terms of clinical research. It is now possible to appreciate the landmark papers that have contributed to the growth of the specialty.

Although this study has included many of the prolific papers in craniofacial research, some important papers were not included in the top 50 list. Polley et al. [18], who historically described external devices, published a preliminary paper on monobloc craniomaxillofacial distraction osteogenesis in 1995. However, this paper did not achieve enough citations to be included in the top 50 list. Kane et al. [19] in 1996 published an enlightening paper on their observations of a marked increase in plagiocephaly without synostosis. They noticed that this occurred at the same time as the American Academy of Pediatrics recommendations to avoid the prone sleeping position as it is related to sudden infant death. Thus, Kane et al. concluded that the back to sleep campaign had a causal relationship with deformational plagiocephaly. Yet this paper was not included in the top 50 most cited papers. This may possibly be as a result of a phenomenon known as 'obliteration by incorporation' $[7,14]$. This is a theory whereby as the subject matter of a published paper becomes 'well known' and 'common knowledge' within it's particular field, it is no longer referenced. This reflects some inherent limitations within this study design. To overcome such limitations, it has been suggested that a more accurate evaluation of the most influential papers is to include the top 50 articles and the reference lists which they contain [14].

It is commendable that over $60 \%$ of the most cited articles originated from the United States. This trend has been noted by many other citation analysis studies [10-12]. According to the Institute of Scientific Information the US holds the highest ranking in all 20 scientific disciplines $[15,16]$. It is speculated that 'national citing' and 'auto citing' is responsible for this trend [20]. American authors have gained a reputation for preferentially citing local papers and American reviewers often have a preference towards accepting local articles which have been sub- mitted to their journals-'national bias' [20,21]. There is also an abundance of craniofacial specialist centers in the USA in comparison to other countries, which may also account for their overwhelming representation in the top 50 list. It is pertinent to acknowledge the limitations of this study design. Obviously citations accumulate over time, therefore it is likely that older papers will have more citations, as they have had a longer period since publication to amass a greater number of citations $[14,22,23]$. Bohannon and Roberts [24] and Marx et al. [25] discussed the lifespan of published papers. Usually a scientific paper is first cited 1-2 years after it has been published and can take up to 10 years to gain it's maximum quantity of citations. To overcome this problem, the 'citation index' can alternatively be used [14]. This is calculated by dividing the number of citations an article has obtained by the number of years since the article was first published. Citation analysis by virtue of it's methodology, can also be affected by different forms of bias. 'Incomplete citing bias' can have a profound adverse effect on citation rates. It includes 'self citing,' 'language bias' i.e., citing only articles published in the English language and 'Omission bias.' 'Omission bias' occurs when authors deliberately omit referencing another paper as both papers have conflicting results [8]. 'Journal bias' occurs when high IF journals only publish articles that are guaranteed to be repeatedly referenced, such as systematic reviews, with the intention of increasing the journals IF $[10,14]$. The authors of this particular study acknowledge other potential limitations arising from this study design. Firstly, the journals searched mainly included high IF surgical, pediatric and genetics journals. However some papers on craniofacial anomalies may have been published in psychology, medical, otolaryngology or low impact journals. The web of knowledge is the most commonly used database for citation analysis, but if another database was used our results may have varied [14]. The readers should also be aware that this study reflects the top cited articles in March/April 2015, but this is a dynamic list as the included papers continue to be referenced at different rates which may alter their ranking over time. Despite these shortcomings, the value of performing a citation analysis is that it highlights the seminal papers that have historically influenced the specialty. By analyzing the top 50 list, future researchers gain a unique insight into the characteristics of a 'classic paper' and can formulate future research ideas based on these characteristics to achieve multiple citations. From this study it is apparent that new surgical techniques are frequently published, so too are discoveries of causal gene mutations in the pathogenesis of these conditions. It is likely that papers written in the English language, originating from the US and involving multicenter studies will be published. By performing a trend analysis it is possible to appreciate the changes in subject matter over 
time. The most cited papers of the 1960's mainly dealt with the pathogenesis of craniosynostosis. Surgical papers dominated the 1970's and 1980's as articles dealt with various reconstructive options and the complications of such procedures. Developments in bone grafting were also introduced during this era. The psychological impact of such anomalies was investigated at this point in time. As the 1990's were introduced there were an upsurge of papers dealing with genetic studies and the implications of various gene mutations. The fibroblast growth factor receptor (FGFR1 and FGFR2) gene mutations were linked to Pfeiffer, Apert's and Crouzon's syndromes. TWIST gene mutations were causative in the Saethre Chotzen syndrome. The surgical papers of the 1990's focused on the distraction techniques and their advantages over the older external techniques. As we progressed into the 2000's genetic studies are once again at the forefront. Mutations of the MSX genes are implicated in disorders of ossification. Surgical papers at this point in time shift to the treatment of craniofacial trauma (Table 2).

Similar to other citation studies, there is an upward trend in the number of papers being published in this specialty in recent years. According to the ISI database there were 1,575 and 2,106 craniofacial publications in the 1990's and 2000's respectively. This was not reflected in the top 50 most cited list but this is likely due to their citable period being far shorter than their older counterparts. Classic citation analysis has become a useful adjunct to the expanding body of research within multiple specialties. It is a comprehensive guide to identify the most influential papers within it's field. This study highlights the historical evolution of craniofacial research from 1960 to the present day. The most cited papers currently in the field of craniofacial include a wide array of clinical surgical procedures and lab based genetic studies of various anomalies. This single compilation of all these top influential papers in craniofacial will help both clinicians and researchers alike to assess the current trend in publications within this specialty. The paper also emphasizes the highly regarded research articles that have influenced evidence based clinical decision-making in craniofacial surgery.

\section{REFERENCES}

1. Buchanan EP, Xue AS, Hollier LHJr. Craniofacial syndromes. Plast Reconstr Surg 2014;134:128e-153e.

2. British Association of Oral and Maxillofacial Surgeons [Internet]. London: Royal College of Surgeons of England; [cited 2015 July 20]. Available from: www.baoms.org.uk/craniofacialsurgery.

3. Hylton JB, Leon-Salazar V, Anderson GC, et al. Multidisciplinary treatment approach in Treacher Collins syndrome. J
Dent Child (Chic) 2012;79:15-21.

4. Garfield E. The impact factor and its rightful use. Anaesthesist 1998;47:439-40.

5. Garfield E. Journal impact factor: a brief review. CMAJ 1999; 161:979-80.

6. Saha S, Saint S, Christakis DA. Impact factor: a valid measure of journal quality? J Med Libr Assoc 2003;91:42-6.

7. Garfield E. 100 citation classics from the Journal of the American Medical Association. JAMA 1987;257:52-9.

8. Seglen PO. Why the impact factor of journals should not be used for evaluating research. BMJ 1997;314:498-502.

9. Hansson S. Impact factor as a misleading tool in evaluation of medical journals. Lancet 1995;346:906.

10. Baltussen A, Kindler CH. Citation classics in anesthetic journals. Anesth Analg 2004;98:443-51.

11. Paladugu R, Schein M, Gardezi S, et al. One hundred citation classics in general surgical journals. World J Surg 2002; 26:1099-105.

12. Fenton JE, Roy D, Hughes JP, et al. A century of citation classics in otolaryngology-head and neck Surgery journals. J Laryngol Otol 2002;116:494-8.

13. Loonen MP, Hage JJ, Kon M. Plastic Surgery Classics: characteristics of 50 top-cited articles in four Plastic Surgery Journals since 1946. Plast Reconstr Surg 2008;121:320e-327e.

14. Yoon DY, Yun EJ, Ku YJ, et al. Citation classics in radiology journals: the 100 top-cited articles, 1945-2012. AJR Am J Roentgenol 2013;201:471-81.

15. Kelly JC, Glynn RW, O’Briain DE, et al. The 100 classic papers of orthopaedic surgery: a bibliometric analysis. J Bone Joint Surg Br 2010;92:1338-43.

16. Institute for Scientific Information. Science citation index expanded 1946-2006 [Internet]. New York: Thomson Reuters; [cited 2015 March/April]. Available from: http:// www.isiwebofknowledge.com/.

17. Mahon NA, Joyce CW. A bibliometric analysis of the 50 most cited papers in cleft lip and palate. J Plast Surg Hand Surg 2015;49:52-8.

18. Polley JW, Figueroa AA, Charbel FT, et al. Monobloc craniomaxillofacial distraction osteogenesis in a newborn with severe craniofacial synostosis: a preliminary report. J Craniofac Surg 1995;6:421-3.

19. Kane AA, Mitchell LE, Craven KP, et al. Observations on a recent increase in plagiocephaly without synostosis. Pediatrics 1996;97:877-85.

20. Campbell FM. National bias: a comparison of citation practices by health professionals. Bull Med Libr Assoc 1990;78: 376-82.

21. Link AM. US and non-US submissions: an analysis of review- 
er bias. JAMA 1998;280:246-7.

22. Callaham M, Wears RL, Weber E. Journal prestige, publication bias, and other characteristics associated with citation of published studies in peer-reviewed journals. JAMA 2002; 287:2847-50.

23. Cole S. Citations and the evaluation of individual scientists. Trends Biochem Sci 1989;14:14.
24. Bohannon RW, Roberts D. Core journals of rehabilitation: identification through index analysis. Int J Rehabil Res 1991; 14:333-6.

25. Marx W, Schier H, Wanitschek M. Citation analysis using online databases: feasibilities and shortcomings. Scientometrics 2001;52:59-82. 